\title{
We've always been antagonistic: Algorithmic resistances and dissidences beyond the Global North
}

\author{
Gabriel Pereira, Aarhus University \\ Bruno Moreschi, Universidade de São Paulo \\ André Mintz, Universidade Federal de Minas Gerais \\ Giselle Beiguelman, Universidade de São Paulo
}

This article has been published in Media International Australia (Special Issue on Algorithmic Antagonisms). This is the Accepted Manuscript, please refer to the published version for citation: https://doi.org/10.1177/1329878X221074792

\section{Introduction: Antagonism in The Paleo-Cybernetic Age}

In 1969, the United States' National Security Advisor Henry Kissinger said that "Nothing important can come from the South. History has never been produced in the South" (Hersh, 1982; see also Arantes, 2021). Such belief seems to find place in much scholarship on the history and practices of computation, including discussions regarding activist and artistic approaches to the inequalities and injustices caused by computational systems. Though with some resistance, much of what is discussed largely concerns the work done in the high-end laboratories, cultural institutions, and tech companies of the so-called Global North. However, as proposed by Rodrigo Ochigame (2020), "Algorithms of oppression have been around for a long time. So have radical projects to dismantle them and build emancipatory alternatives." Our suggestion in this article is indeed to consider how these unacknowledged histories can help us (artists, activists, and researchers in the field of art and computation) to more deeply appreciate the foundations on which we create our resistances to contemporary computing.

Departing from the case of Brazil, we argue in this article that we've always been antagonistic. Our goal is to show that everyday practices of technological dissidence in the country, as well as the many tactical ruptures created by artists and activists, represent a history of algorithmic antagonism which we must recover and learn from. Moreover, we discuss how these deep roots, such as the appropriation of technologies and creation of alternative information networks, are related to contemporary forms of algorithmic antagonism. Through bridging historical and contemporary perspectives on computation, we seek to offer an alternative framing that breaks from the dominant Global North canon. In this sense, we take Brazil not as a single center for such conceptualization, but one example among many other sites of counter-hegemonic algorithmic practices. As we will make clear, this discussion needs to be continued from other localities and perspectives. 
We begin by going 50 years back in time, to the early seventies. During the peak of the Brazilian civil-military dictatorship, while Kissinger was plotting coup d'états in Chile and beyond (Hersh, 1982), the artist Waldemar Cordeiro was making history by creating some of the first computer art works in the world. ${ }^{1}$ Cordeiro's innovative practice involved using algorithms to procedurally modify scanned images, all of this in a moment when computation and cybernetics as we know them today were just becoming a reality. "The Woman Who Is Not B.B." (Fig. 1) is a digitized version of a photo depicting a Vietnamese woman crying, a victim of the ongoing war. The work was created by Cordeiro in 1971, and is shown as a piece of paper printed directly from the IBM 360/44 computer. The image itself is composed through a matrix of ASCII characters, a grid which only becomes a coherent image when seen from a distance as opposed to the structural composition of the image, which is all that is visible at a close range.

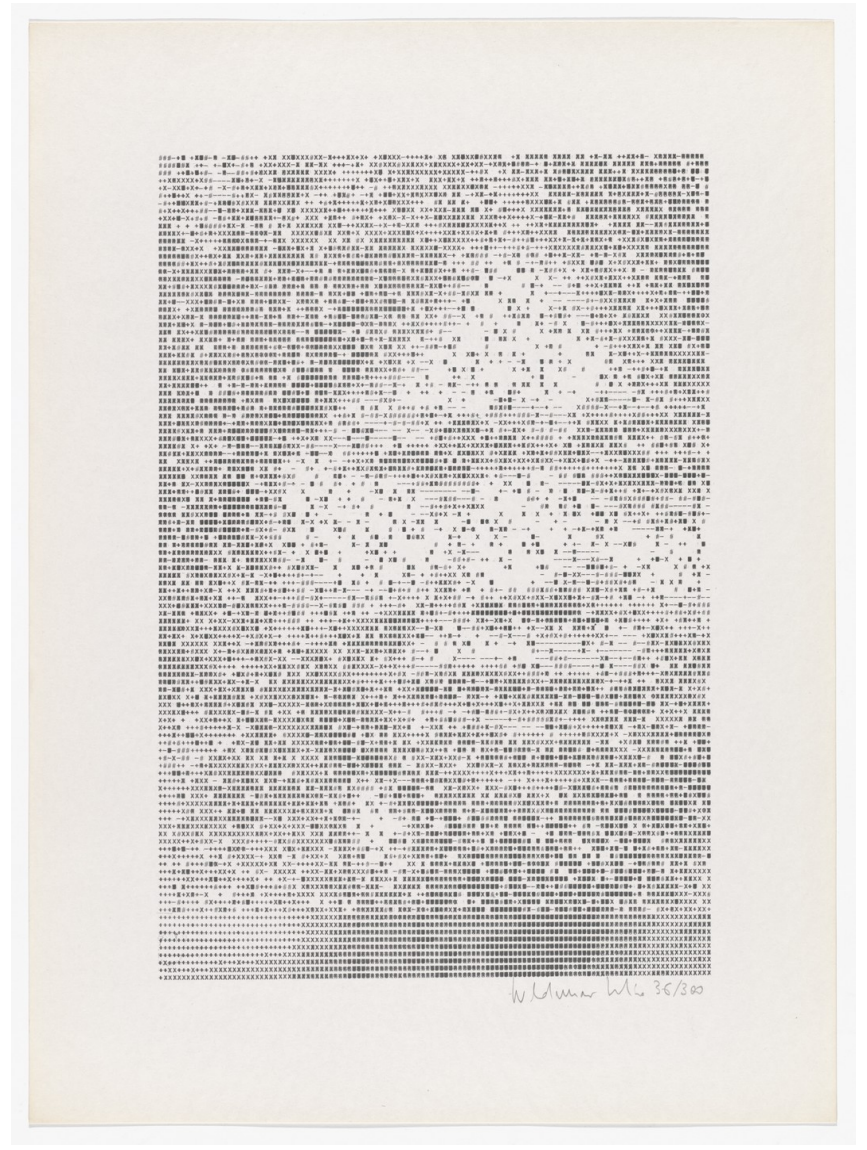

Figure 1: “The Woman Who Is Not B.B.” (1971), a computer artwork created by Waldemar Cordeiro (with support from physicist Giorgio Moscati).

\footnotetext{
${ }^{1}$ In the exhibit catalogue Computer Plotter Art, written in 1969, Cordeiro positioned his innovative work alongside other pioneering computer artists that were working at the same time or before. These artists were mostly located in Europe and the USA. Some references include the Cybernetic Serendipity exhibit at the ICA (London), the Tendencies 4 exhibit (Zagreb), and other exhibitions and conferences in Japan, USA, etc.
} 
The work by Cordeiro, a result of his partnership with physicist Giorgio Moscati, is not a direct replica of the original photo: it was algorithmically altered to introduce noise through random changes, thus corroding the original image and how it looks. The act of transforming the printed photograph into digital code and algorithmically manipulating it sought to express a social and political commentary. The first aspect of this critical stance is the deliberate choice of image, which gives visibility to the humanitarian catastrophe and violence inflicted by the USA through the Vietnam war. ${ }^{2}$ The second aspect is in the algorithmic manipulation, which is used in order to particularly "highlight the structural makeup of the picture itself" (Arantes, 2018) by programmatically adding noise. The image thus is intentionally "glitched," no longer a smooth representation of the world as often attempted by photographic practices. The third aspect, the title, a reference to the mass media of the time, contrasts the visual representation of the Vietnamese woman's algorithmic re-rendering and the image of B.B. (a moniker for Brigitte Bardot). The Vietnamese woman and B.B. are different not only in the role they play in mass media (i.e. cinema/high fashion glamour vs. war image), but also in the intersection between the feeling they transmit (i.e. suffering/crying vs. joy/beauty), their materiality (i.e. noise vs. perfection), and their legibility (i.e. cinematic sharpness vs. semi-illegibility).

Already in what he termed "The Paleo-Cybernetic Age", in the year 1971, Cordeiro's experiment with the algorithmic representation of images didn't have the goal of directly representing reality in a figurative sense (like many artists of the Global North were trying to do at the time). Instead, he sought to subvert the machinic functioning, and highlight other potential ways of computing images which tried to be creative, critical, engaged with the politics of the time, and mindful of the materiality of the emerging medium of computing. By making a computer artwork that problematized an image of war, Cordeiro separated himself from "the computer art developed in the international arena, which focused on highly abstract and metalinguistic forms" (Arantes, 2018: 94). Cordeiro subverted the apparatus of computation through the structure (process, algorithm, and re-presentation) of the artwork itself (see Flusser 2013[1985]; Machado 2005; 2015).

In a moment when computers still filled entire rooms of high-end university laboratories, such as those used by Cordeiro and Moscati at the University of São Paulo, the potential for computation to be critical and political, legible and illegible, serves as our starting point for considering algorithmic antagonisms. Our goal is demonstrating how these antagonisms are not just made in opposition to hegemonic systems of computation, but also formed through appropriations and contaminations of dominant technologies. In this sense, our argument extends what Velkova \& Kaun (2021: 535) define as algorithmic resistance: "a complicit form of

\footnotetext{
${ }^{2}$ It is worth noting that Brazil was going through the harshest phase of its dictatorship at the time, which was sponsored and architected by the USA. In Brazil, actions deemed "politically subversive" were at risk of being censored, and many activists and artists were arrested, tortured, exiled, or killed for questioning the dictatorship. Cordeiro's choice of image, thus, was subversive also in the sense that it transgressed what was allowed by Brazil's truculent dictatorship at the time, through its questioning of the USA's military operations in Vietnam.
} 
resistance, one that does not deny the power of algorithms but operates within their framework, using them for different ends." As the Introduction to this special issue indicates, algorithmic antagonism does not just involve resistance through the technical algorithm itself. Very often, and in line with critical algorithm studies approaches (see Dourish, 2016; Seaver, 2017), this resistance is sociotechnical — formed through social and political pushback around how algorithms are created, used, or imagined. In this sense, algorithmic antagonism is understood as the broad activist intervention in the "composite of human-algorithm relations" (Amoore, 2020). Such depiction of algorithms locates them across a broad "stack," including their emergence and operation in society - e.g. algorithms' philosophical origins, their conditions of creation in companies/universities, or even their material harms to marginalized communities (see Azar et al, 2021).

Artists and activists have long sought to work through the "properties and logics" of (digital) technologies to do things differently (see e.g. Sack, 2018; Machado, 2005; Treré, 2018). Our conceptual goal in this article is to suggest connections between this longer history and the emergent conceptualization of "algorithmic antagonism." As such, we conceptualize it in a fluid manner, as it has taken different shapes through time. For example, some of the works we discuss involve technological appropriations which do not necessarily seek to change hegemonic technological conditions, but use them as a vector for other forms of power redistribution. These are distinct, but also similar, to antagonisms which seek to directly challenge the technological system by re-envisioning the logics of information technologies through structural changes. Moreover, some of these projects are not directly engaged with either digital or algorithmic technologies per se, but are nevertheless important if we seek to understand the digital as a non-essentialist category, bearing continuities with prior technological paradigms of communication and information. In connecting the issue of algorithmic antagonisms with other previous technological paradigms, we argue for some sense of continuity between, for instance, the antagonistic practice of infiltrating the postal service communication networks and that of computational networks. Our point is that they share similar stances and tactical practices towards information systems which should be historically connected and accounted for. In a sense, what characterizes the long history of algorithmic antagonisms we discuss is not their character, or if they are complete or finalized projects, but that they act tactically outside the norm to intervene and disrupt the "dominant semiotic regime," creating spaces for thinking and doing otherwise (Raley, 2009).

As previously indicated, our focus is on a specific context of algorithmic antagonism: Brazil. First, we present the historical power found in technological dissidences, particularly as technological systems have been appropriated as a resistance to unequal power structures. Next, we discuss how particular tactical ruptures in the history of art and media activism have sought to contaminate and re-envision networked technologies. Based on these two engagements, we discuss the particular notions of algorithmic antagonism that two contemporary projects 
(PretaLab/Olabi and Silo/Caipiratech) advance, and relate these to their historical counterparts. Finally, we conclude by outlining what lessons can be learned by bridging historical and contemporary notions of algorithmic antagonism, both for practice and scholarship.

\section{Dissidences: Gambiarra and the dynamics of appropriation}

In discussing our topic, it is crucial that we move beyond a simplistic framing that would understand technology in Brazilian art and activism simply as local applications of foreign technology. Scholars of Science and Technology Studies Medina, Marques and Holmes (2014) indicate that such approaches stereotypically treat Latin America's relationship with computers as being "imported magic." Contrary to this notion, it is crucial to take technological reinvention and adaptation seriously, focusing on specific forms of technological thought and practice that take form in the region. In this section, we pursue this approach starting with the discussion of the theory and practice of gambiarra.

The notion of gambiarra has had a strong reverberation in the context of Brazilian art ${ }^{3}$ and scholarship (see Bruno, 2017; Menotti, 2017; Rosas, 2008). It is a word that has emerged from common parlance in Brazil and which usually denotes precarious and improvised technical assemblages which aim to overcome particular needs with limited and often non-ideal supplies and tools. Authors have highlighted gambiarra's resemblance with hacking and technological disobedience, and have also framed it within broader concepts such as "techno-vernacular creativity" (Tragtenberg, Albuquerque and Calegario, 2021). Possible translations of gambiarra to English would be kludge or makeshift, and there are also notable similarities with the Indian notion of jugaad and its associated concept of "frugal innovation" (see Rai, 2015).

This process of appropriation, adaptation, and improvisation also has more specific historical relationships with the Anthropophagic Movement, an artistic avant-garde movement led, in 1928, by thinkers such as the writer Oswald de Andrade, the painter Tarsila do Amaral, and the literary critic Antônio de Alcântara Machado. In their manifesto, they advocated precisely for the appropriation (and re-invention) of what's foreign: "Today we are cannibals. That's how we've reached perfection. The modern experience (...) ended up awakening in each one of us the appetite to pierce the neighbor with a fork." (Machado 1928, our translation). Eighty years later, Beiguelman (2010) updated this notion to the field of art and technology with her concept of technophagy ("tecnofagia"), which she defines as "aiming to describe combinatory operations between tradition and innovation, unusual arrangements between artisanal and scientific knowledge, revalidation of high and low tech (...) and essentially

\footnotetext{
${ }^{3}$ A central reference of the approach of Gambiarra in digital art is project Gambiologia, led by Brazilian artist and curator Fred Paulino, see https://www.gambiologia.net/. Brazilian artist and filmmaker Cao Guimarães has also developed an extensive photographic series documenting Gambiarras in its various forms, see http://www.caoguimaraes.com/foto/gambiarras/.
} 
micropolitical actions of critical appropriation of media and technical resources." These references indicate how gambiarra is not solely a technical practice but one that is deeply related with art and aesthetics.

Among different approaches to the notion of gambiarra, scholars Messias and Mussa (2020) propose to situate it as a key concept and epistemological operator for understanding political and aesthetic dimensions of technology in a broader sense. In dialogue with contemporary postcolonial and complexity theories, the authors mobilize gambiarra to name "a form of knowledge" characterized by multiplicity and by an untetheredness with respect to crystallized and hegemonic forms of logic and reasoning. They argue that, as a concept, gambiarra should not be restricted to the Brazilian context or to the word's original denotative meaning. Quite the contrary, they propose it should name forms of technological thought and practice restricted neither by geography nor socioeconomic status.

While in such approach gambiarra would not seem to be necessarily antagonistic, it should be highlighted that its multiplicity and untetheredness are improvisational responses to precariousness which, when established as a structural condition of inequality, is a typical consequence of colonization and oppression. As such, gambiarra should be understood as situated technological thought and practices born out of resistance. In addition, the concept of gambiarra is not simply a matter of assimilation of "imported magic" but, rather, as a somewhat distinct form of thought and practice characterized by reinvention and critical repurposing. It is able to not only rewrite the implicit script (Akrich, 1992) of a given technical object, but also of inventing alternative technologies on its own right.

What's particularly interesting about this notion of gambiarra as a form of antagonism is that it finds resonance in everyday media and technological practices in Brazil. A representative example is how media and digital piracy are widespread in the country, perhaps more so than any other place in the world (see Feltrin, 2020). An everyday practice, it involves the creation of alternative networks through which software, movies, music, and other content can be shared or sold in an accessible manner. It is seen by participants as a creative solution and way of breaking boundaries imposed by the rich IP-holders in the Global North, thus "[providing] the necessary response to international monopolies and their local collaborators" (Dent, 2012: 44). That is, in the context of gross inequality (both technological and economical), it is through such gambiarras that "we [Brazilians] avoid paying the ridiculous prices that citizens of First World countries don't have to pay" (ibid). These antagonisms, though they may not directly reshape how technology works in the country, represent how everyday technological relations are marked by dissidences to the hegemonic order. 
While the concept of gambiarra has been used to understand how technological antagonisms have operated in recent times, it also enables putting into perspective a deeper history of technological development and appropriation as a response to oppression. In its derogatory sense, the word gambiarra has been used in common parlance to undermine tactical technological development led by oppressed groups. A clear case of this is how, due to the country's historically entrenched racism, the technology produced by Black people has been historically delegitimated and unrecognized. However, as discussed by scholar Taís Oliveira (2021), "the development and use of technology is not new to Black people, as Brazil's economy was built from the beginning on the work of this population that brought from Africa a very well-developed technical knowledge." The historian Cunha Junior $(2010 ; 2015)$ has devoted much work to pinpointing the precise techniques and knowledges brought by the enslaved, which range from construction architecture to textile technologies ${ }^{4}$. In this sense, Silva and Dias (2020) have indicated how the resistance of the quilombos, the communities of fleeing and freed enslaved workers, was founded on their own technological prowess. The "quilombos" made use of ancestral techniques and knowledge in their spatial arrangement, but also in iron welding, creating sophisticated artifacts "probably used for production, but also for war" (ibid: 7). Much like the notions of gambiarra, these historical dissidences are often discredited, understood as less-evolved than their white and/or Global North counterparts. Giving value and understanding these histories allows us to better comprehend that new and old networks of appropriation and technological production are much more prolific than hegemonic technological practice may take them to be.

\section{Tactical ruptures: Contaminating networked technologies}

The processes of technological resistance can be understood from different historical transformations, one of which is how artistic practices have changed since the beginning of the 20th century. Since the European avant-gardes, artistic works no longer echo the idea of North American art critic Clement Greenberg that the meaning of the work is within it. Partly due to the advancement of technology, the field expanded to practices that understand the artist "as a manipulator of signs" (Foster 1996). However, this shift was not entirely similar in all places. Brazilian art critic Cristina Freire (2006) draws attention to how the dematerialization of art theorized by researchers in the USA and Europe (Lippard, 1997; Popper, 2007) reverberated in contexts such as Latin America through practices that were much less centered on art itself. In Latin America, the "crisis of the art object" (Zanini 2018) took place in the context of the 1970s. It importantly emerged as a resistance to the censorship of the time, occasioned by the many civil-military dictatorships in the region. Such artistic practices sought to more incisively "be confused with everyday life" (Freire, 2006), in order to infiltrate communication networks for politically subversive ends. Our proposal is to understand such contaminations of networked

\footnotetext{
${ }^{4}$ For material examples of this, see the collection of the AfroBrasil museum, in São Paulo: http://www.museuafrobrasil.org.br/acervo-digital
} 
technologies as important seeds for technological resistances (see also Chandler and Neumark, 2005).

Art historian Walter Zanini is a key reference in the process of infiltrating art in the gaps of the networked informational systems of the 1970s. As a curator of the University of São Paulo's Museum of Contemporary Art (MAC USP), he used the museum as an operational space not only for exhibiting finished artworks, but also as an active experimentation site. In this sense, the series of exhibitions Jovem Arte Contemporânea (JAC) were marked not by formal exhibitions, but by the creation of spaces for exchanges and collaborations in a moment when the dictatorship sought to limit them. This also included a fundamental process of making electronic equipment available to young artists who did not have means to access them otherwise. It was through these networks that Zanini, for example, made available the first Sony Porta Pack video cameras in Brazil to artists.

His activities as a professor were also marked by an understanding of art that supported such infiltrations in official systems marked by repression and curtailment of freedom of expression. Using ideas such as "networked solidarity" (Sayão, 2016), Zanini promoted in his classrooms a mail art network in Latin America (from the late 1960s until its presentation at the XVI Bienal de São Paulo in 1981), involving the participation of artists from various countries, especially Latin America. In a moment when many of these countries were under dictatorial regimes, this mail network evaded state control and oversight. This expansion of the use of a technology (the mail) occurred as a reaction to a threat: "If collective memory was threatened in public spaces [because of the dictatorship], it was reinforced in alternative networks of virtual encounters" (Freire, 2006: 69, our translation). Tadeu Jungle, one of the student-artists who participated at the time in this long term network, still remembers its intensity:

We were very young and we couldn't create this network without Zanini's help. Unlike many of us, he was fully aware that he was contaminating a system. Zanini often wrote an invitation in English to accompany the postal artwork we sent. When we sent a postcard art, months later we received not only a response from the artist that had received it, but also other postcards from artists from that country (or even a list with addresses of other people interested in participating in this exchange). So our network grew and grew. (Jungle, 2021, personal communication).

This concept of postal art was dynamic and ranged from occasional exchanges via mail between two artists to larger collective exhibitions held at the museum. It was not rare for the works created to subvert the traditional materials of the post office, as occurred for example in 1975 with a postcard created by Paulo Bruscky for MAC USP, in which he mixed official stamps and seals with fictional ones he had created. It was also common for artists to curate exhibitions through the mail art networks. Colombian artist Jonier Marin, for example, was responsible for 
the 1976 Paper and Pencil exhibition at MAC USP, where he activated a network of 45 artists from Latin America and Europe. Each of the artists mailed a pencil drawing on paper next to a passport-sized photograph. The theme was open and many artists subverted the passport photographs by producing images with non-traditional poses - thus ironically questioning both the officiality of travel control and the difficulty of actual travel under the dictatorship.

While there are significant differences between postal and digital networks, we argue that their similarities should be accounted for in a deeper historical framing of algorithmic antagonism. For such experiences were indeed forms of hacking and infiltration into established communication systems in which the artistic gesture cannot be understood in the individual object of the letter that has been posted/received but, rather, in the performative act of posting by which the object has been inserted in a given system. Therefore, Paulo Bruscky's work does not fall too far from net art practices in the 1990's. Many of the postal works by Bruscky bore, on their back (Fig. 2), a message inscribed with a custom-made stamp in which it read "Hoje, a arte é este comunicado" (Today, the art is this communication in English) (see Bruscky, 2006[1976]). It wouldn't be far-fetched to bring this idea close to the iconic 1997 net art piece Simple Net Art Diagram, by MTAA (M.River \& T.Whid Art Associates), in which a bold red arrow indicated the cable between two computers with the words "Art happens here". In both cases the artistic gesture is placed in the act of intervention in the connection that is performed through sophisticated information systems that are repurposed by the artist. 


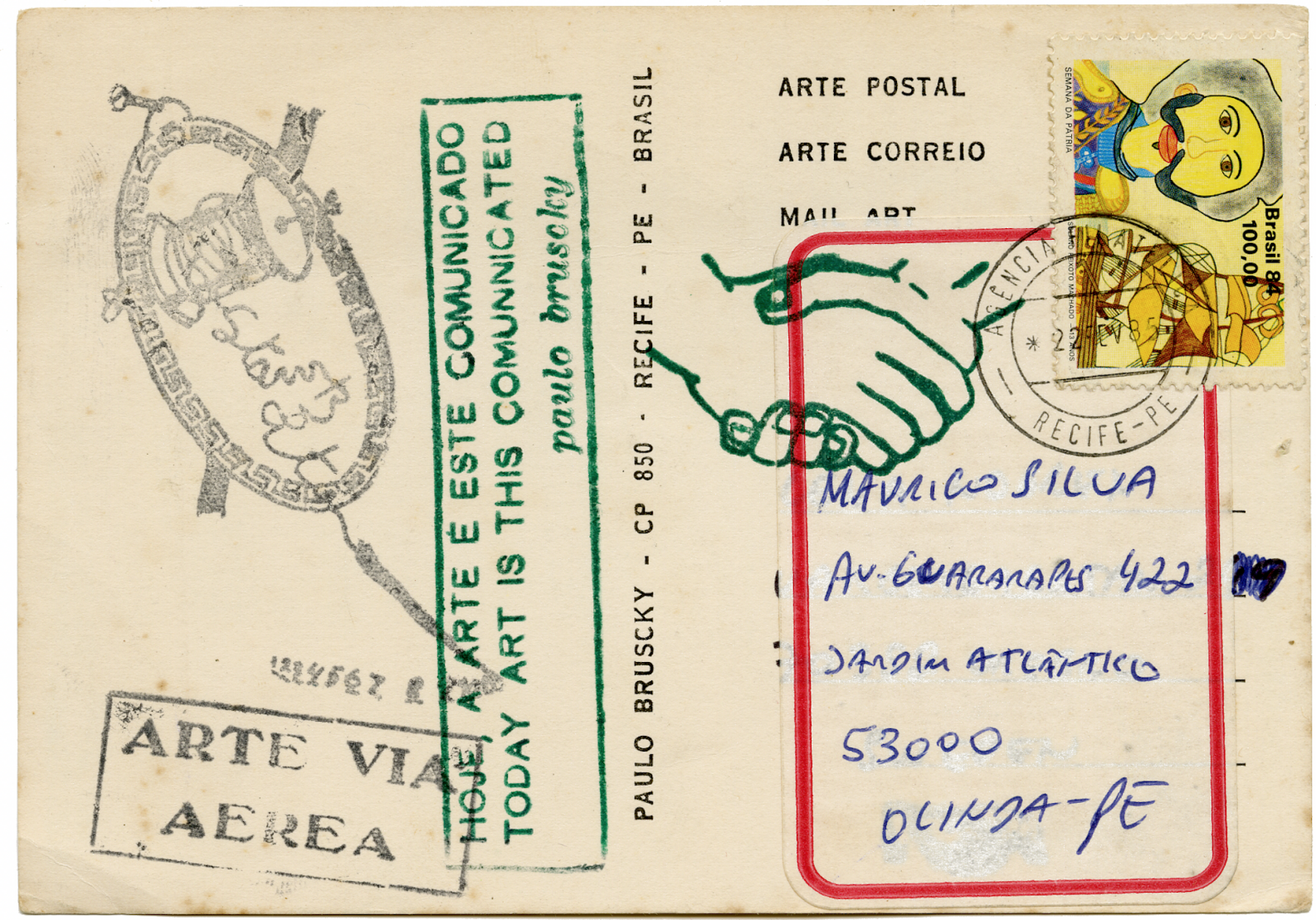

Figure 2: Verse from the postal artwork Repetition Poem (1985), by Paulo Bruscky, with the phrase "Hoje, a arte é este comunicado" (Translated: "Today, the art is this communicated") and "Arte via Aérea" (Translated: “Air Art", a pun with "Air Mail”). Additionally two other stamps mark the work: A handshake between two hands, perhaps symbolizing the communication/solidarity act, and that of an unwinding sewing thread spool.

The notion of infiltration into networked systems also appears in individual artistic projects in Brazil at that time. One of the most emblematic cases was the project "Insertions in Ideological Circuits" by Cildo Meireles which, in one of its versions (1970), involved printing anti-US messages on returnable Coca-Cola bottles using silk-screen. The text (e.g. an instructional image of how to turn the bottle into a molotov cocktail) was printed in white, making it hard to detect on empty bottles, but clearly legible over the dark liquid. Once consumed, the empty bottles were returned to the local stores to be refilled, but now having a political message in their circulation process. Meireles also infiltrated political messages by stamping money notes of the time with the question "Who killed Herzog?", in reference to the murder of journalist Vladimir Herzog by the Brazilian military regime - framed as a suicide by the dictatorship. These infiltrations of systems continue in the current artist's works, including stamps on money notes with the question "Who killed Marielle?" (referencing the 2018 murder of activist and councilor Marielle Franco in Rio de Janeiro). 
Beyond the realm of art, experiments of infiltration and the creation of alternative networks were also conducted through media activism initiatives, often in an interchange with the arts. Between the 1980's and the 2000's, several groups and organizations in the country led projects in community and alternative media. These included local (and often "clandestine") TV and radio stations, as well as educational projects focused on self-representation through video and other media resources. Among these, we would like to highlight one particular project, "Canal Motoboy" (Motoboy Channel), which lies on the interface between activism and art. The project was carried out in São Paulo, in 2007, by a group of 12 "motoboys" - a Brazilian Portuguese word for freelance motorcycle delivery workers - and idealized by the Catalan artist Antoni $\mathrm{Abad}^{5}$, with the contribution of several local artists. Using 'camera phones' (a novelty at the time), these motoboys recorded their daily experiences in São Paulo and shared those videos online. This project attracted much attention from artistic and academic institutions as an example of counter-hegemonic media representation by precarious workers, which were commonly stigmatized by mainstream media (see Targino and Gomes, 2011).

The consolidation of the internet and its subsequent platformization may have shifted the framing with regards to participatory media and its implications, but labor issues have remained central for understanding media technologies today. In this sense, Canal Motoboy could be framed as an antecedent to more recent projects dealing with the issue of platformized labor, such as the net art "Exch w/ Turkers", the activist Instagram page "Treta no Trampo", and the work of Rio de Janeiro photographer and delivery worker Allan Weber. This continuity, however, should not overshadow the difference between these two moments. For, to some extent, in "Canal Motoboy", media technologies were an addition to the workers' daily lives, as media for self-representation, while in these more recent cases, there is a further intertwinement of labor and technologies, making the use of such artifacts much more integrated to the very subject of the artworks. In the former case, media technologies were taken as emancipatory instruments. In contrast, in the latter cases, their status is more complicated, since today media technologies are prominent instruments of oppression and, therefore, the very sites of struggle and targets of antagonistic practices performed by those works.

These different uses of networked technology, away from their intended use, highlight how artists and activists sought to evade centralized control, be it the dictatorial regimes or mainstream media and platforms. Much like the "intercommunication network" created by liberation theologians in Brazil described by Ochigame (2020), the mail art and alternative media activism networks we presented aimed at contaminating and rupturing the normative systems in the search for "networked solidarity." Within the broader and more contemporary setting of algorithmic antagonism, such cases bring to light the deeper history of practices of infiltration in information systems. Moreover, they display how multiple forms of resistance have historically

\footnotetext{
${ }^{5}$ See the project's website at: https://megafone.net/saopaulo/about?lang=1

${ }^{6}$ See: https://exchanges. withturkers.net/

${ }^{7}$ See: https://twitter.com/tretanotrampo
} 
existed, particularly in how alternative information systems are built and developed, bypassing dominant media and technological paradigms of their time.

\section{The contemporary practices of algorithmic antagonism}

By acknowledging this deeper history of technological antagonism, it is possible to shed new light over contemporary responses of Brazilian activists and artists to algorithmic injustices. In this section, we discuss two contemporary projects, their particular approach to algorithmic antagonism, and how they relate to previous tactical ruptures and dissidences.

A key question in recent debate has been: "Who makes the algorithms?" This issue has led to different initiatives that seek to redistribute the power given to the makers of technology, most often white, male, and from the Global North (see e.g. Broussard, 2019). Olabi ${ }^{8}$ emerged as a response to these questions. Originally founded as a makerspace/fab lab, the organization has worked within three axes: "diversity, technology, and social innovation" (Bahia, 2021). Located in the city of Rio de Janeiro, Olabi has run several projects seeking to expand notions of technological production. An example of this is the "High-Tech Sewing" workshop, aimed at people over 60 (see Fig. 3). Working together with local communities at the Complexo de Favelas da Maré (Maré Favela Complex), they have brought together "the idea of mixing embroidery, cutting and sewing knowledge, with 3D printing and open electronics, to build wearable technologies" (ibid).

Rather than centering notions of transferring technological skills, Olabi's projects have sought to "create networks and democratize access to innovation and technology." Their "High-Tech Sewing" workshop antagonizes the exclusionary character of how "wearable technologies" are hegemonically created through the uncaring deployment of high-tech algorithms by companies such as Apple or FitBit. By broadening who gets involved in the making and doing of smart technologies-senior citizens are seldom included as digital "makers" in their own right - the project also offers an alternative imaginary of how algorithmic creations may not be restricted to Global North companies or laboratories, as well as how they may support alternative goals. Experiences such as these point to situated and critical instantiations of so-called DIY (Do It Yourself) maker cultures - or gambiarra, as we've previously defined - in a more collective and communitarian Do-It-With-Others approach.

\footnotetext{
${ }^{8}$ See: https://www.olabi.org.br/
} 


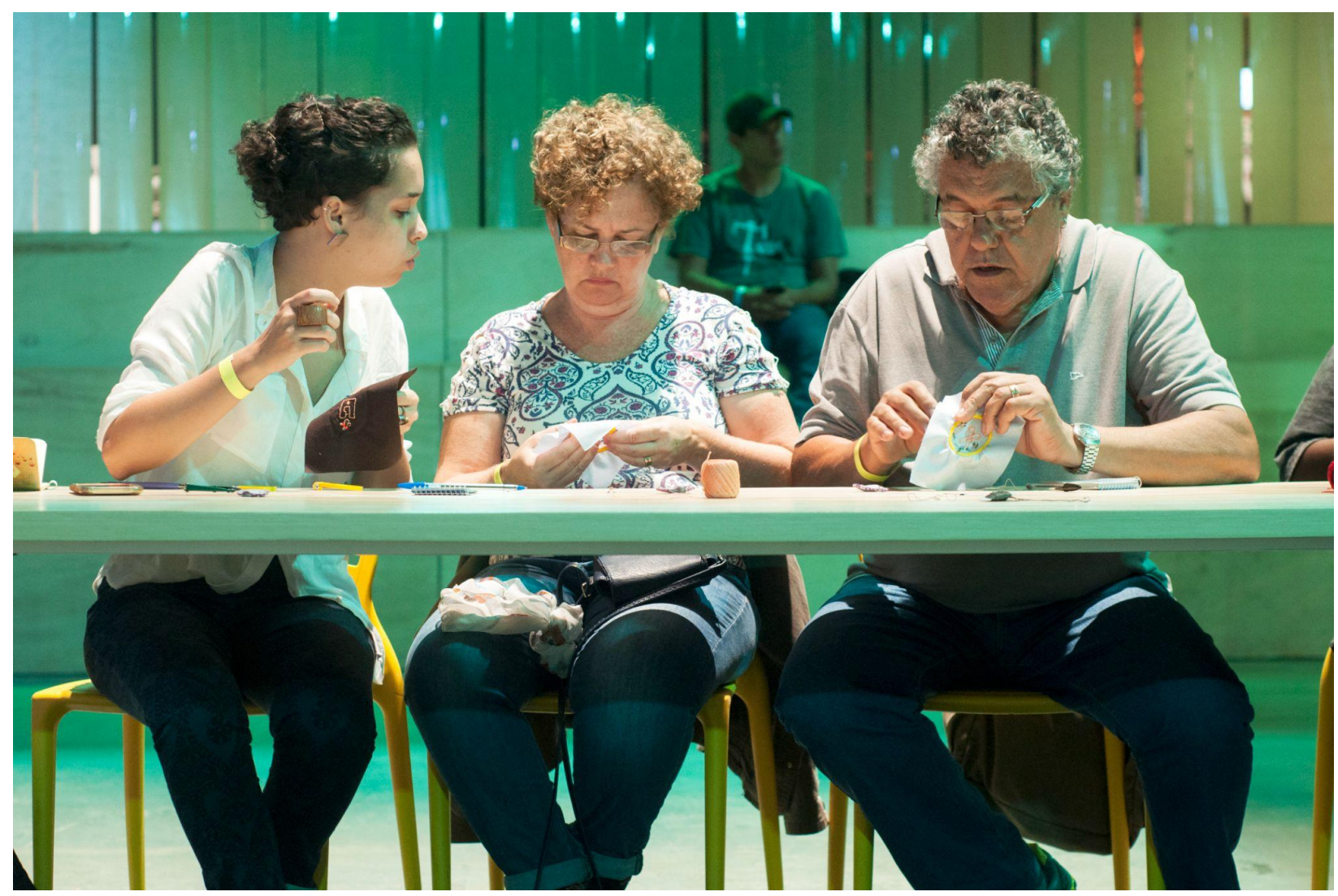

Figure 3: "High-Tech Sewing” workshop at the Rio Design Week 2016. (Photo: Victor Domingues/Olabi)

Other actions by Olabi have considered the racism present in algorithmic technology production. The "Pretalab" project", coordinated by the collective together with other collaborators, sought to survey, map, and build connections between Black women programmers in Brazil, to support diversity in technology, and to generally rethink technological production. Through the conduction of the survey, "Pretalab" was able to assess and understand the systematic exclusion of Black women from the technological market, but also to create a network with the over 600 women they reached. The outcome of this was a website, showcasing these women and their skills, where one can learn more about each one of them. "Pretalab" brings attention to how algorithmic racism (see Silva, 2020) takes shape through the systematic exclusion of Black people from the possibility of creating algorithmic systems, which in itself ripples through the technologies we use in everyday life. However, the project goes beyond giving Black women visibility: it creates networks through which they can organize and support each other. Through activism and community organizing, Olabi and the Pretalab project enable the production of alternative communities of practice, and to re-think inclusion and diversity from the perspective of those most affected. It represents, as such, a particular form of antagonism that relates to previously discussed attempts to create alternative networks of practice and build networked solidarity. This is not a form of algorithmic antagonism through the direct

${ }^{9}$ See: https://www.pretalab.com/ 
construction of new algorithmic systems, but a crucial intervention in the social, cultural, and political "conditions of emergence" (Amoore, 2020) of algorithmic systems, pointing to the importance of activism for the construction of more diverse and just algorithmic cultures.

Another contemporary project showing other perspectives for technology development is Silo $^{10}$, situated in the countryside of Rio de Janeiro state. It is a rural art and technology lab which develops its own form of algorithmic antagonism by shifting the technological grounds over a different axis: from urban and cosmopolitan areas to natural and farming landscapes. The organization holds different activities including artistic residencies, workshops, workgroups, and, soon, a school. The project is focused on notions such as citizen innovation and exchange/ collaboration, merging intuitive and traditional knowledge with what is hegemonically recognized as science and technology.

Also acting as a scholar, Silo founder Cínthia Mendonça (2015) discusses that an inspiration to her project is the notion of Temporary Autonomous Zones by anarchist theorist Hakim Bey, with an interest in the dialectics between permanence and ephemerality. This dynamic is taken as central to an approach to landscape and technology that is committed with environmental concerns. "Caipiratech Lab" (literally translated as countryman-tech lab), one of Silo's main programmes, addresses topics such as agroecology, bioarchitecture, and energy generation in rural areas, with close collaboration with its local community.

Silo is proudly led by a team of women, and also promotes activities aimed at gender and racial equality, such as the feminist event EncontrADA. In 2017, for example, EncontrADA hosted workshops, mentorship sessions, and other activities around the theme of "Ancestral Technology and Knowledge," thus engaging with algorithms and digital technologies through the lens of often unacknowledged forms of production from rural communities (much as we've previously described in the case of the "quilombos"). Silo thus offers antagonistic paths for technological development not only by showing the importance of a strong commitment to diversity, but by showing how the local needs and specificities of rural communities may be typically overshadowed by the universalist ambition of a cosmopolitan understanding of technology and progress.

By framing these examples under the overarching theme of algorithmic antagonism, perhaps we are extending the conceptual limits of both algorithms and antagonism. Algorithms are, evidently, integral parts of contemporary digital technologies, but here, through the cases we have brought to our discussion, we seek to emphasize a decentering movement by which the specificity of digital technologies is put into brackets. This allows for focusing, rather, on their larger cultural and sociopolitical entanglements. Although the case of Waldemar Cordeiro may indeed involve the creation of antagonistic algorithms per se, the other cases we've offered -

\footnotetext{
${ }^{10}$ See: https://silo.org.br/en/
} 
the history of gambiarra, appropriation of information networks by mail artists, and the contemporary expansion of technology production and use by seniors, Black developers, or even rural communities - are all based instead on a broader tactical and activist stance to technological and algorithmic production and use. By suggesting to broaden the debate on algorithmic resistance we are not denying the relevance of algorithms "proper", but rather highlighting a relational approach that shifts away from an essentialist perspective that disconnects algorithms from the context in which they are produced and applied to. Antagonism, in this sense, is not only going against a system of power, but a generative disposition towards thinking of alternatives - through networks and solidarity, diversity and situatedness.

\section{Conclusion: We've always been antagonistic}

To Kissinger, nothing important can come from the South - since the notion of "important" for him is intrinsically related to the idea of "History" (with capital H of Hegemony). In that sense, he is indeed right: "History" has been appropriated and extracted from the South, made invisible in how computational activism and art has been widely presented and discussed. Our proposal suggests that contemporary forms of algorithmic antagonism are not entirely novel - they are actually contemporary derivations from historical artistic and activist approaches to technology.

Through this article, our goal was to point out how the activism and art with technological practice in Brazil has been formed around different notions of antagonism. The notion of gambiarra helps tying together some of these practices by naming the multiple forms of technological knowledge insubordinate to hegemonic technological practice (Messias and Mussa, 2020). Thus, looking back, we can perceive antagonism not simply in direct opposition, but also in alternative forms of thinking and making technology aiming to surpass conditions of oppression and precariousness which continue to exist in current times.

By bridging historical and contemporary perspectives on computation and networks, we seek to offer an alternative framing that breaks from the dominant Global North canon. Recognizing this longer genealogy of technological dissidences and ruptures can strengthen current practices against technological oppressions. That is, once we broaden the scope of algorithmic resistance to all of these different forms of resistance through and with technology, we become sensitive to how we could build today's technological systems otherwise.

The goal here is not to romanticize the marginalization or its ensuing erasures, but to understand that there is a lot of possibility hidden in (or at least effaced by) these conditions. Recognizing how we've always been antagonistic means recovering wider possibilities for doing and thinking technology, especially considering the terraforming conducted by technological development and implementation (see e.g. Couldry \& Mejias' (2019) data colonialism). If, as the saying goes, "they who frame the question determine the answer," it's time our questions take us 
(and our history) seriously for thinking of resistant futures. This analysis is thus just a beginning: there are many underdiscussed aspects of the history of art, activism, and technology in the Global South that deserve to be explored. Our suggestion is that retrieving these deeper antagonist histories from a wider set of localities and contexts will help to produce a much more radical and inclusive picture of an alternative notion of computation.

\section{References}

Akrich M (1992) The de-scription of technical objects. In: Bijker WE and Law J (eds) Shaping Technology/Building Society: Studies in Sociotechnical Change. Cambridge: MIT Press, pp. 205-224.

Arantes P (2018) Digital Art in Brazil. In: Linda Candy, Ernest Edmonds, and Fabrizio Poltronieri (eds) Explorations in Art and Technology. London: Springer, pp. 93-100.

Arantes P (2021) Waldemar Cordeiro e a Arteônica: reescrituras da arte digital no Brasil e na América Latina. MODOS: Revista de História da Arte 5(2): 87-98. DOI: 10.20396/modos.v5i2.8663931.

Azar M, Cox G and Impett L (2021) Introduction: ways of machine seeing. AI \& SOCIETY. DOI: $10.1007 / \mathrm{s} 00146-020-01124-6$.

Bahia S (2021) For more diversity in technology. In: Benfield DM, Moreschi B, Pereira G, et al. (eds) Affecting Technologies, Machining Intelligences. CAD+SR. Available at: https://book.affecting-technologies.org/for-more-diversity-in-technology/ (accessed 26 April 2021).

Beiguelman, Giselle (2010) Tecnofagias emergentes na Artemidia.br. Revista Marginalia + Lab 1: 6-15.

Broussard M (2019) Artificial Unintelligence: How Computers Misunderstand the World. Cambridge: MIT Press.

Bruno F (2017) Objetos técnicos sem pudor: gambiarra e tecnicidade. Revista ECO-Pós 20(1): 136-149. DOI: 10.29146/eco-pos.v20i1.10407.

Bruscky P (2006) Arte Correio e a grande rede: hoje, a arte é este comunicado. In: Ferreira G, Cotrim C (eds) Escritos de artistas: anos 60/70. Rio de Janeiro: Zahar, pp. 374-379.

Couldry N and Mejias UA (2019) The Costs of Connection: How Data Is Colonizing Human Life and Appropriating It for Capitalism. Stanford: Stanford University Press.

Cunha Junior H (2010) Tecnologia Africana na Formação Brasileira. Rio de Janeiro: CEAP.

Cunha Junior H (2015) Arte e tecnologia africana no tempo do escravismo criminoso. Revista Espaço Acadêmico (166).

da Silva LCR and Dias RB (2020) As tecnologias derivadas da matriz africana no Brasil: um estudo exploratório. Linhas Críticas 26: 1-16. DOI: 10.26512/lc.v26.2020.28089.

Dent AS (2012) Piracy, Circulatory Legitimacy, and Neoliberal Subjectivity in Brazil. Cultural Anthropology 27(1): 28-49. DOI: 10.1111/j.1548-1360.2012.01125.x.

Dourish P (2016) Algorithms and their others: Algorithmic culture in context. Big Data \& Society 3(2). DOI: 10.1177/2053951716665128.

Feltrin R (2020) Brasil é $1^{\circ}$ do mundo em consumo de pirataria online, diz estudo. In: UOL Available at:

https://www.uol.com.br/splash/noticias/ooops/2020/12/21/brasil-e-do-mundo-1-em-consu mo-de-pirataria-online-diz-estudo.htm (accessed 28 July 2021). 
Flusser V (2013) Towards a Philosophy of Photography. London: Reaktion Books.

Foster H (1996) The Return of the Real: The Avant-Garde at the End of the Century. Cambridge: MIT Press.

Freire C (2006) Arte conceitual. Rio de Janeiro: Jorge Zahar Editor.

Hersh SM (1982) The Price of Power. The Atlantic. Available at: https://www.theatlantic.com/magazine/archive/1982/12/the-price-of-power/376309/ (accessed 28 July 2021).

Lippard LR (1997) Six Years: The Dematerialization of the Art Object from 1966 to 1972. Berkeley: University of California Press.

Machado A (2005) Tecnologia e arte contemporânea: como politizar o debate. Revista de Estudios Sociales (22): 71-79.

Machado A (2015) Waldemar Cordeiro: o brasileiro precursor da arte mediada por computadores. Revista ECO-Pós 18(1): 27-35.

Machado A de A (1928) Abre-Alas. Revista de Antropofagia, 1 May. Available at: https://digital.bbm.usp.br/bitstream/bbm/7064/1/45000033273.pdf.

Medina E, Marques I da C and Holmes C (2014) Beyond Imported Magic: Essays on Science, Technology, and Society in Latin America. Cambridge: MIT Press.

Mendonça, Cinthia (2015) Espaços periféricos projetados sobre a terra. Cadernos de Subjetividade 18: 9-22.

Menotti G (2017) A gambiarra e a perspectiva da prototipagem. Vazantes 1(1): 202-205.

Ochigame R (2020) Informatics of the Oppressed. Logic 11.

Messias J and Mussa I (2020) Por uma epistemologia da gambiarra: complexidade e paradoxo nos objetos técnicos digitais. MATRIZes 14(1): 173-192. DOI:

10.11606/issn.1982-8160.v14i1p173-192.

Oliveira T (2021) Is a new economy possible? Perspectives from socio-technical networks. In: Benfield DM, Moreschi B, Pereira G, et al. (eds) Affecting Technologies, Machining Intelligences. $\mathrm{CAD}+\mathrm{SR}$. Available at:

https://book.affecting-technologies.org/is-a-new-economy-possible-perspectives-from-so cio-technical-networks/ (accessed 26 April 2021).

Popper F (2007) From Technological to Virtual Art. Leonardo. Cambridge: MIT Press.

Rai, Amit S (2015) The Affect of Jugaad: Frugal Innovation and Postcolonial Practice in India's Mobile Phone Ecology. Environment and Planning D: Society and Space 33(6): 985-1002. doi: 10.1177/0263775815598155.

Raley R (2009) Tactical Media. Minneapolis: U. of Minnesota Press.

Rosas R (2008) Gambiarra: alguns pontos para se pensar uma tecnologia recombinante.

GAMBIARRA 1(1). 1: 19-26. DOI: 10.22409/gambiarra.vli1.29620.

Sack W (2019) The Software Arts. Cambridge: The MIT Press.

Sayão B (2016) Solidariedade em rede: arte postal na América Latina. Mestrado em Estética e História da Arte. Universidade de São Paulo, São Paulo. DOI:

10.11606/D.93.2016.tde-27012016-124815.

Seaver N (2017) Algorithms as culture: Some tactics for the ethnography of algorithmic systems.

Big Data \& Society 4(2). DOI: 10.1177/2053951717738104.

Silva T (2020) Racismo Algorítmico em Plataformas Digitais: microagressões e discriminação em código. In: Silva T (ed.) Comunidades, Algoritmos e Ativismos Digitais. São Paulo: LiteraRUA, pp. 121-137. 
Silva LCR da and Dias R de B (2020) As tecnologias derivadas da matriz africana no Brasil: um estudo exploratório. Linhas Críticas 26: 1-16. DOI: 10.26512/lc.v26.2020.28089.

Targino, Maria das Graças, and Alisson Dias Gomes (2011) Comunicação para mudança social: projeto Canal*Motoboy. Intercom: Revista Brasileira de Ciências da Comunicação 34: 197-217. doi: 10.1590/S1809-58442011000200011.

Tragtenberg J, Albuquerque G and Calegario F (2021) Gambiarra and Techno-Vernacular Creativity in NIME Research. International Conference on New Interfaces for Musical Expression. PubPub. Available at: https://nime.pubpub.org/pub/aqm27581/release/1 (accessed 28 June 2021).

Treré E (2018) From digital activism to algorithmic resistance. In: Meikle G (ed.) The Routledge Companion To Media And Activism. Routledge, pp. 367-375. DOI: 10.4324/9781315475059-39.

Velkova J and Kaun A (2021) Algorithmic resistance: media practices and the politics of repair. Information, Communication \& Society 24(4): 523-540. DOI: 10.1080/1369118X.2019.1657162.

Zanini W (2018) Vanguardas, Desmaterialização, Tecnologias Na Arte. São Paulo: Editora Martins Fontes. 